\title{
Are Mast Cells MASTers in Cancer?
}

\author{
Gilda Varricchi ${ }^{1+}$, Maria Rosaria Galdiero ${ }^{1+}$, Stefania Loffredo ${ }^{1+}$, Giancarlo Marone ${ }^{2}$, \\ Raffaella lannone ${ }^{1}$, Gianni Marone ${ }^{1,3 *}$ and Francescopaolo Granata ${ }^{1}$
}

\begin{abstract}
'Department of Translational Medical Sciences (DiSMeT), Center for Basic and Clinical Immunology Research (CISI), University of Naples Federico II, Naples, Italy, ${ }^{2}$ Department of Public Health, University of Naples Federico II, Monaldi Hospital Pharmacy, Naples, Italy, ${ }^{3}$ Institute of Experimental Endocrinology and Oncology "Gaetano Salvatore" (IEOS), National Research Council (CNR), Naples, Italy
\end{abstract}

OPEN ACCESS

Edited by:

Fulvio D'Acquisto, Queen Mary University of London, UK

Reviewed by:

Francesca Levi-Schaffer, Hebrew University of Jerusalem, Israel Marc Benhamou, Institut national de la santé et de la recherche médicale (INSERM), France

*Correspondence: Gianni Marone marone@unina.it

tThese authors have contributed equally to this work.

Specialty section: This article was submitted to Inflammation,

a section of the journal

Frontiers in Immunology

Received: 15 February 2017

Accepted: 27 March 2017

Published: 12 April 2017

Citation:

Varricchi G, Galdiero MR, Loffredo S, Marone $G$, lannone $R$, Marone $G$ and Granata F (2017) Are Mast Cells MASTers in Cancer?

Front. Immunol. 8:424. doi: 10.3389/fimmu.2017.00424
Prolonged low-grade inflammation or smoldering inflammation is a hallmark of cancer. Mast cells form a heterogeneous population of immune cells with differences in their ultra-structure, morphology, mediator content, and surface receptors. Mast cells are widely distributed throughout all tissues and are stromal components of the inflammatory microenvironment that modulates tumor initiation and development. Although canonically associated with allergic disorders, mast cells are a major source of pro-tumorigenic (e.g., angiogenic and lymphangiogenic factors) and antitumorigenic molecules (e.g., TNF- $\alpha$ and IL-9), depending on the milieu. In certain neoplasias (e.g., gastric, thyroid and Hodgkin's lymphoma) mast cells play a pro-tumorigenic role, in others (e.g., breast cancer) a protective role, whereas in yet others they are apparently innocent bystanders. These seemingly conflicting results suggest that the role of mast cells and their mediators could be cancer specific. The microlocalization (e.g., peritumoral vs intratumoral) of mast cells is another important aspect in the initiation/progression of solid and hematologic tumors. Increasing evidence in certain experimental models indicates that targeting mast cells and/or their mediators represent a potential therapeutic target in cancer. Thus, mast cells deserve focused consideration also as therapeutic targets in different types of tumors. There are many unanswered questions that should be addressed before we understand whether mast cells are an ally, adversary, or innocent bystanders in human cancers.

Keywords: angiogenesis, cancer, inflammation, lymphangiogenesis, mast cells

\section{INTRODUCTION}

Mast cells were first identified in human tumors and named by Paul Ehrlich $(1,2)$. These cells are present in all classes of vertebrates, and it has been estimated that they have emerged $>500$ million years ago, long before the development of adaptive immunity (3). Mast cells are distributed throughout nearly all human tissues and often in close proximity to epithelia, fibroblasts, blood and lymphatic vessels, and nerves (4).

Human mast cells form a heterogeneous population of cells with differences in their ultrastructure, morphology, mediator content, and surface receptors $(4,5)$. Human mast cells derive from $\mathrm{CD} 34^{+}, \mathrm{CD} 117^{+}$pluripotent hematopoietic stem cells, which arise in the bone marrow (6). Mast cell progenitors enter the circulation and subsequently complete their maturation in tissues. These cells store and release upon activation a wide spectrum of biologically active mediators that individually have been shown to have potential positive or negative effects on various target cells (7). Increasing evidence indicates that mast cells act as sentinels of the surrounding environment, with the 
capacity to rapidly perceive tissue insults and initiate biochemical programs of inflammation or repair.

Mast cells are activated not only by $\operatorname{IgE}(8)$, specific antigens (5), and superallergens $(9,10)$, the main mechanisms which account for their function in allergic disorders, but also by a plethora of immunologic and non-immunologic stimuli (11-14). Figure 1 schematically illustrates the constellation of surface receptors expressed by human mast cells.

Mast cells and their mediators have been canonically associated with a detrimental role in allergic diseases $(4,5)$, but these cells can induce a protective immune response of the host against noxious substances $(16,17)$, viral $(18)$ and microbial pathogens (19). Interestingly, epidemiological $(20,21)$ and experimental studies (22) indicate an inverse association between IgE-mediated allergies and cancer, implying tumor-protective effect of IgE.

The initiation and progression of cancer are multistep processes characterized by the accumulation of a variable number of genetic and epigenetic alterations (23). The immunosurveillance system recognizes and eliminates mutant cells constantly generated (24). However, immune-resistant cancer cells can slip through this system and proceed to develop tumors (25).

Normal microenvironment [immune cells, fibroblasts, blood and lymphatic vessels, and interstitial extracellular matrix (ECM)] plays a central role in maintaining tissue homeostasis and is a barrier to tumorigenesis (26). Incorrect signals (chemokines, cytokines, reactive oxygen species, lipid mediators, etc.) from an aberrant microenvironment alter tissue homeostasis and initiate/ promote tumor growth. Thus, the multiple interactions between stromal and tumor cells are crucial for the initial phases of tumor development.

Prolonged low-grade inflammation or smoldering inflammation is a hallmark of cancer $(27,28)$. Several cells of the innate and adaptive immune system (macrophages, mast cells, lymphocytes, neutrophils, NK, and NK T cells) are stromal components of the inflammatory microenvironment that can promote the development of experimental and human tumors $(29,30)$.

\section{WHY ARE MAST CELLS INCREASED IN TUMORS?}

The presence of mast cells in human tumors, initially reported by Ehrlich $(1,2)$, was extended by Eugen Westphal (31). Tumorassociated mast cells (TAMCs) are present in the microenvironment of several human solid (32-46) and hematologic tumors (47-55).

Peritumoral and/or intratumoral mast cell density is increased in different types of human cancer (56). Tumor cells produce several chemotactic factors acting on receptors expressed by mast cells. Stem cell factor (SCF) $(13,57)$, also produced by

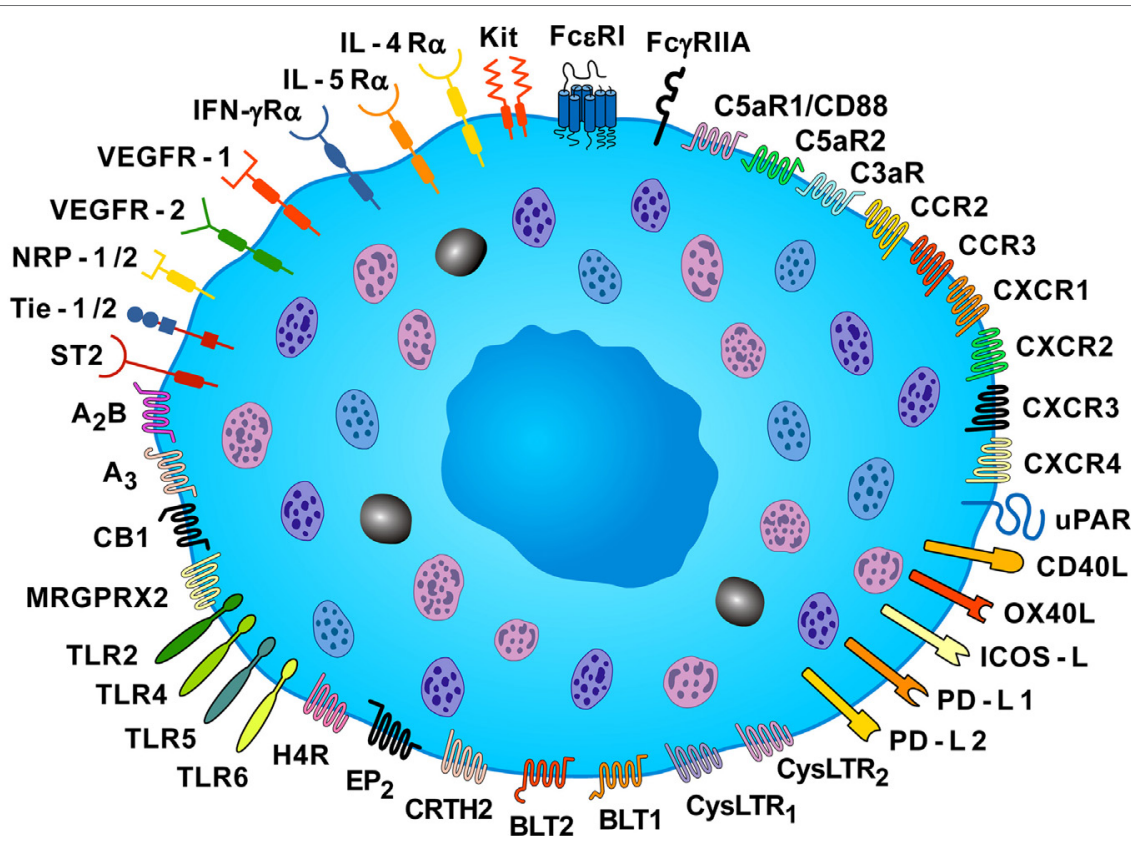

FIGURE 1 Some of the surface receptors expressed by human mast cells. Human mast cells express the tetrameric high-affinity receptor for lgE (FCeRl) and the Fc $\gamma$ RIIA, and their cross-linking induces the release of pro-inflammatory and immunomodulatory mediators. Mast cell expresses the KIT receptor (CD117), which is activated by stem cell factor. These cells express a plethora of receptors, such as toll-like receptor (TLR) 2, TLR4, TLR5, TLR6, receptors for chemokines (CCR2, CCR3, CXCR1, CXCR2, CXCR3, and CXCR4), two receptors for cysteinyl leukotriene (CysLTR1 and CysLTR2), two leukotriene B4 receptors (BLT1 and BLT2), the prostaglandin $\mathrm{D}_{2}$ receptor $(\mathrm{CRTH} 2)$, the prostaglandin $\mathrm{E}_{2}$ receptor $\left(\mathrm{EP}_{2}\right)$, the cannabinoid $\mathrm{CB} 1$ receptor, two adenosine receptors $\left(\mathrm{A}_{2 \mathrm{~B}}\right.$ and $\left.\mathrm{A}_{3}\right)$, and histamine $\mathrm{H}_{4}$ receptor (H4R). Mast cells express receptor for various cytokines (IL-4R $\alpha$, IL-5R $\alpha$, IFN- $\gamma$ R $\alpha$, ST2). The MAS-related G protein coupled receptor (MRGPRX2) can be activated by neuromuscular blocking drugs, neuropeptides (SP and VIP), and eosinophil cationic proteins (MBP and EPX). These cells also express receptors for vascular endothelial growth factors (VEGFR1 and VEGFR2), and VEGFR co-receptors, neuropilin-1 and neuropilin-2 (NRP1 and NRP2), for anaphylatoxins (C5aR1/ CD88, C5aR2, and C3aR), and the high-affinity urokinase plasminogen activator receptor (uPAR). Human mast cells also express co-receptors for T-cell activation [CD40 ligand (CD4OL), tumor necrosis factor superfamily member 4 (OX4OL), inducible costimulator ligand (ICOS-L), programmed death ligands (PD-L1 and PD-L2)] [Slightly modified with permission of Springer Nature from Borriello et al. (15)]. 
mast cells (58), activates the mast cell Kit receptor (CD117), vascular endothelial growth factors (VEGFs) act on VEGFR-1 and VEGFR-2 (38, 59), angiopoietin 1 (Ang1) acts on Tie2 receptor (60), and CXCL8/IL-8 acts on CXCR1 and CXCR2 (61). Mast cells express CCR2, CXCR2, and CXCR3, which can be important for TAMC localization because their respective ligands, CCL2, CXCL1, and CXCL10, are produced by human tumors $(35,38) . \mathrm{PGE}_{2}$ and histamine are chemotactic for mature mast cells through the engagement of $\mathrm{EP}_{2}$ receptor $(62,63)$ and $\mathrm{H}_{4} \mathrm{R}$, respectively (64). $\mathrm{LTB}_{4}$ may be involved in recruitment of mast cell progenitors from the circulation via the activation of BLT1 and BLT2 (65). Finally osteopontin (OP), which is upregulated in human cancer (35), induces mast cell migration (66) and degranulation (35).

\section{THE CONTRIBUTION OF MAST CELLS TO CANCER IS TUMOR DEPENDENT}

The increasing heterogeneity of different subsets of immune cells (e.g., macrophages, Thelper cells, mast cells, neutrophils, NK, NK $\mathrm{T}$ cells, etc.), their plasticity, and their reciprocal interactions have complicated the comprehension of the role of the inflammatory microenvironment in tumor initiation and development (29).

A large number of studies have tried to identify the contributory functions of TAMCs in tumor growth. In the majority of studies, TAMCs appear functional-either actively promoting or suppressing tumor development and growth-whereas in a few cases they may be simple inert bystanders. In several studies, mast cells appear to play a pro-tumorigenic role in human (Table 1) and experimental tumors (Table 2). Evidence for an antitumorigenic role for mast cells is provided in Table 3. Studies supporting a non-contributing role of mast cells in tumors are outlined in Table 4.

In several solid tumors, such as thyroid $(38,61)$, gastric $(75-77,122)$, pancreas $(37,84,85,94,95,123)$, bladder cancers (67), and Merkel cell carcinoma (33), mast cells always appear to be pro-tumorigenic. Similarly, in several hematologic tumors, such as different types of Hodgkin's (53-55) and non-Hodgkin's lymphoma $(48,50,52)$, and plasmacytoma $(47,96)$, mast cells are associated with poor prognosis. There are certain tumors such as breast cancer $(106,107,109)$ in which mast cells always appear to play an antitumorigenic role. The role of mast cells in the pathogenesis of human melanomas is still unclear and appears to depend on both the microlocalization of these cells (43) and the subtypes of tumor (83).

These apparently conflicting results are intriguing and suggest that the role of mast cells and their mediators in tumors could be cancer specific. Figure 2 schematically illustrates the role of mast cells in different human tumors.

\section{ROLE OF TAMCs IN TUMOR ANGIOGENESIS AND LYMPHANGIOGENESIS}

Angiogenesis, the formation of new blood vessels, is an essential process for supplying growing malignant tissues with essential
TABLE 1 | Pro-tumorigenic role of mast cells in human tumors.

\begin{tabular}{|c|c|c|}
\hline Type of cancer & Mast cell staining & Reference \\
\hline $\begin{array}{l}\text { Angioimmunoblastic T-cell } \\
\text { lymphoma }\end{array}$ & Tryptase & (50) \\
\hline Bladder & Tryptase & $(67)$ \\
\hline Colorectal & $\begin{array}{l}\text { Giemsa } \\
\text { Toluidine blue/tryptase } \\
\text { Tryptase }\end{array}$ & $\begin{array}{c}(68) \\
(69) \\
(70-73)\end{array}$ \\
\hline Cutaneous lymphoma & Tryptase & $(48)$ \\
\hline Esophagus & Toluidine blue & $(74)$ \\
\hline Follicular lymphoma & Tryptase & (51) \\
\hline Gastric & $\begin{array}{l}\text { Toluidine blue } \\
\text { Chymase } \\
\text { Tryptase }\end{array}$ & $\begin{array}{c}(75) \\
(76) \\
(77,78)\end{array}$ \\
\hline Hepatocellular & Tryptase & (79) \\
\hline Hodgkin's lymphoma & Tryptase & $(53-55)$ \\
\hline Lung & $\begin{array}{l}\text { Tryptase } \\
\text { CD117 }\end{array}$ & $\begin{array}{c}(80,81) \\
(82)\end{array}$ \\
\hline Malignant pleural effusion & $\begin{array}{l}\text { May-Gruenwald-Giemsa } \\
\text { toluidine blue }\end{array}$ & (35) \\
\hline Melanoma & $\begin{array}{l}\text { Gene expression/toluidine blue } \\
\text { Tryptase }\end{array}$ & $\begin{array}{c}(83) \\
(41,45)\end{array}$ \\
\hline Merkel cell carcinoma & Tryptase & (33) \\
\hline Pancreas & Tryptase & $(37,84-86)$ \\
\hline Plasmacytoma & $\begin{array}{l}\text { Toluidine blue } \\
\text { Tryptase }\end{array}$ & $\begin{array}{l}(47) \\
(49)\end{array}$ \\
\hline Prostate & Tryptase & $(36,40,87,88)$ \\
\hline $\begin{array}{l}\text { Splenic marginal zone } \\
\text { lymphoma }\end{array}$ & Tryptase & $(52)$ \\
\hline Thyroid & Tryptase & $(38,61)$ \\
\hline
\end{tabular}

nutrients and oxygen (124). Lymphangiogenesis, the formation of new lymphatic vessels, is important in the development of metastases (124). Judah Folkman, the father of angiogenesis, suggested that mast cells and macrophages could be attracted by chemotactic molecules produced by tumor cells and could be an important source of proangiogenic factors (125). Several groups have demonstrated that mast cells produce several proangiogenic (VEGF-A, VEGF-B, and FGF-2) (126-130) and lymphangiogenic factors (VEGF-C and -D) $(38,59,131)$. In addition, we have found that VEGFs are chemotactic for mast cells (59), indicating that mast cells are a target, in addition to be a source, for VEGFs (132). Several studies have highlighted the association and/or the correlation in human tumors between increased mast cell density and angiogenesis by evaluating the expression of the proangiogenic isoform VEGF-A (42, 45, 70, $80,96,123)$.

The VEGF-A gene can be alternatively spliced to form the proangiogenic VEGF- $\mathrm{A}_{165}$ and the antiangiogenic VEGF- $\mathrm{A}_{165} \mathrm{~b}$ (133). The vast majority of the studies performed so far evaluated only the proangiogenic isoforms, whereas in certain tumors the antiangiogenic VEGF- $\mathrm{A}_{165} \mathrm{~b}$ isoform is dominant (134). This finding suggests that the majority of results on VEGF-A plasma 
TABLE 2 | Pro-tumorigenic role of mast cells in experimental tumors.

\begin{tabular}{|c|c|c|}
\hline Type of cancer & Mast cell staining & Reference \\
\hline \multirow[t]{2}{*}{ Bladder cancer } & Toluidine blue & (89) \\
\hline & Tryptase & $(67)$ \\
\hline Cholangiocarcinoma & Toluidine blue & $(46)$ \\
\hline \multirow[t]{3}{*}{ Colon } & Toluidine blue/proteases & $(90)$ \\
\hline & Alcian blue/toluidine blue & (91) \\
\hline & Chloroacetate esterase & $(71)$ \\
\hline Cutaneous lymphoma & Toluidine blue & $(48)$ \\
\hline Hepatocellular & NE & (13) \\
\hline Malignant pleural effusion & May-Gruenwald-Giemsa/toluidine blue & $(35)$ \\
\hline \multirow[t]{4}{*}{ Melanoma } & NE & $(92)$ \\
\hline & Alcian blue-safranin & (14) \\
\hline & $\mathrm{NE}$ & (93) \\
\hline & Gene expression/toluidine blue & (83) \\
\hline \multirow[t]{4}{*}{ Pancreas } & Toluidine blue & $(94)$ \\
\hline & Tryptase & $(84,85)$ \\
\hline & CD117 & (95) \\
\hline & Tryptase & $(37)$ \\
\hline Plasmacytoma & Toluidine blue & $(96)$ \\
\hline \multirow[t]{2}{*}{ Prostate } & Tryptase/toluidine blue & $(40)$ \\
\hline & Toluidine blue & $(87,97)$ \\
\hline \multirow[t]{3}{*}{ Skin } & Chloroacetate esterase/hematoxylin & $(98)$ \\
\hline & Chloroacetate esterase & (11) \\
\hline & Chloroacetate esterase/toluidine blue & $(99)$ \\
\hline Thyroid & Tryptase & $(38,61)$ \\
\hline $\begin{array}{l}\text { Waldenstrom's } \\
\text { macroglobulinemia }\end{array}$ & CD117/FceRl/tryptase & $(100)$ \\
\hline
\end{tabular}

levels in cancer need to be reinterpreted or require repeating with tools that can differentiate between the two isoforms of VEGF-A (135). For instance, we have recently demonstrated that human neutrophils, under certain circumstances, can produce both pro- and antiangiogenic isoforms of VEGF-A (136). The role of different pro- and antiangiogenic isoforms of VEGFs produced by TAMCs in primary cancers and in the formation of metastases needs further investigation.

Human mast cells produce different matrix metalloproteinases (e.g., MMP-9) (137) and proteases (tryptase and chymase), which regulate the digestion of ECM favoring the implantation of cancer cells in an aberrant microenvironment $(13,98)$.

Vascular endothelial growth factor-C, released by melanoma cells (138), TAMs (139), and TAMCs (59), likely represents a major lymphangiogenic factor in this tumor. Mast cells can be found in metastatic lymph nodes of cancer patients (140), and the role of lymphangiogenic factors in the formation of metastasis should be further addressed.

Epithelial-to-mesenchymal transition (EMT) is a mechanism by which tumor cells gain metastatic features and contribute to chemotherapy drug resistance $(141,142)$. In addition, in the context of tumors, EMT can generate cells with stem-like properties (e.g., stemness) (143). We have demonstrated that mast cells can induce EMT and stem cell features in human cancer through the production of CXCL8/IL-8 (61).
TABLE 3 | Antitumorigenic role of mast cells in tumors.

\begin{tabular}{|c|c|c|}
\hline Type of cancer & Mast cell staining & Reference \\
\hline \multicolumn{3}{|l|}{ Experimental tumors } \\
\hline \multirow[t]{2}{*}{ Intestine } & $\begin{array}{l}\text { Chloroacetate esterase/ } \\
\text { chymase }\end{array}$ & (101) \\
\hline & Tryptase/CD117 & $(102)$ \\
\hline Melanoma & $\mathrm{NE}$ & $(103)$ \\
\hline Prostate & Toluidine blue & $(40)$ \\
\hline \multirow[t]{2}{*}{ Skin } & Tryptase/CD117 & $(102)$ \\
\hline & Giemsa & $(104)$ \\
\hline \multicolumn{3}{|l|}{ Human tumors } \\
\hline Diffuse large B-cell lymphoma & Tryptase & $(105)$ \\
\hline \multirow[t]{4}{*}{ Breast cancer } & CD117 & $(106)$ \\
\hline & Tryptase & $(107)$ \\
\hline & Alcian blue/Giemsa & (108) \\
\hline & CD117 & $(109)$ \\
\hline Colorectal & Tryptase/chymase & $(110)$ \\
\hline Lung & Tryptase/chymase & $(111)$ \\
\hline Mesothelioma & Tryptase/chymase & $(112)$ \\
\hline Melanoma & Tryptase/chymase & $(43)$ \\
\hline \multirow[t]{2}{*}{ Non-small-cell lung cancer } & Tryptase & (113) \\
\hline & Tryptase/chymase & $(114)$ \\
\hline Ovarian cancer & Tryptase & $(115)$ \\
\hline Pancreas & CD117 & (71) \\
\hline Prostate & CD117 & $(116)$ \\
\hline
\end{tabular}

NE, not examined.

TABLE 4 | Non-contributing role of mast cells in tumors.

\begin{tabular}{llc}
\hline Type of cancer & Mast cell staining & Reference \\
\hline Experimental tumors & & \\
\hline Colorectal & Wright-Giemsa & $(117)$ \\
\hline Skin & $\begin{array}{l}\text { Toluidine blue/chloroacetate } \\
\text { esterase }\end{array}$ \\
\hline
\end{tabular}

Human tumors

\begin{tabular}{lll}
\hline Colorectal & Tryptase & (119) \\
\hline Non-small cell lung cancer & Giemsa & (120) \\
\hline Renal & Toluidine blue
\end{tabular}

\section{THE ROLE OF MAST CELLS VARIES ACCORDING TO THE STAGE OF TUMORS}

A recent study found that low mast cell count in perilesional stroma of deeply invasive melanomas predicted poor survival (43). By contrast, mast cell density was not correlated with prognosis in superficially invasive melanomas. The latter findings suggest that the role of mast cells in melanoma is dependent also on the stage of the tumor. The role(s) of these cells in human and experimental melanoma requires additional studies. 


\section{Roles of Mast Cells in Human Tumors}

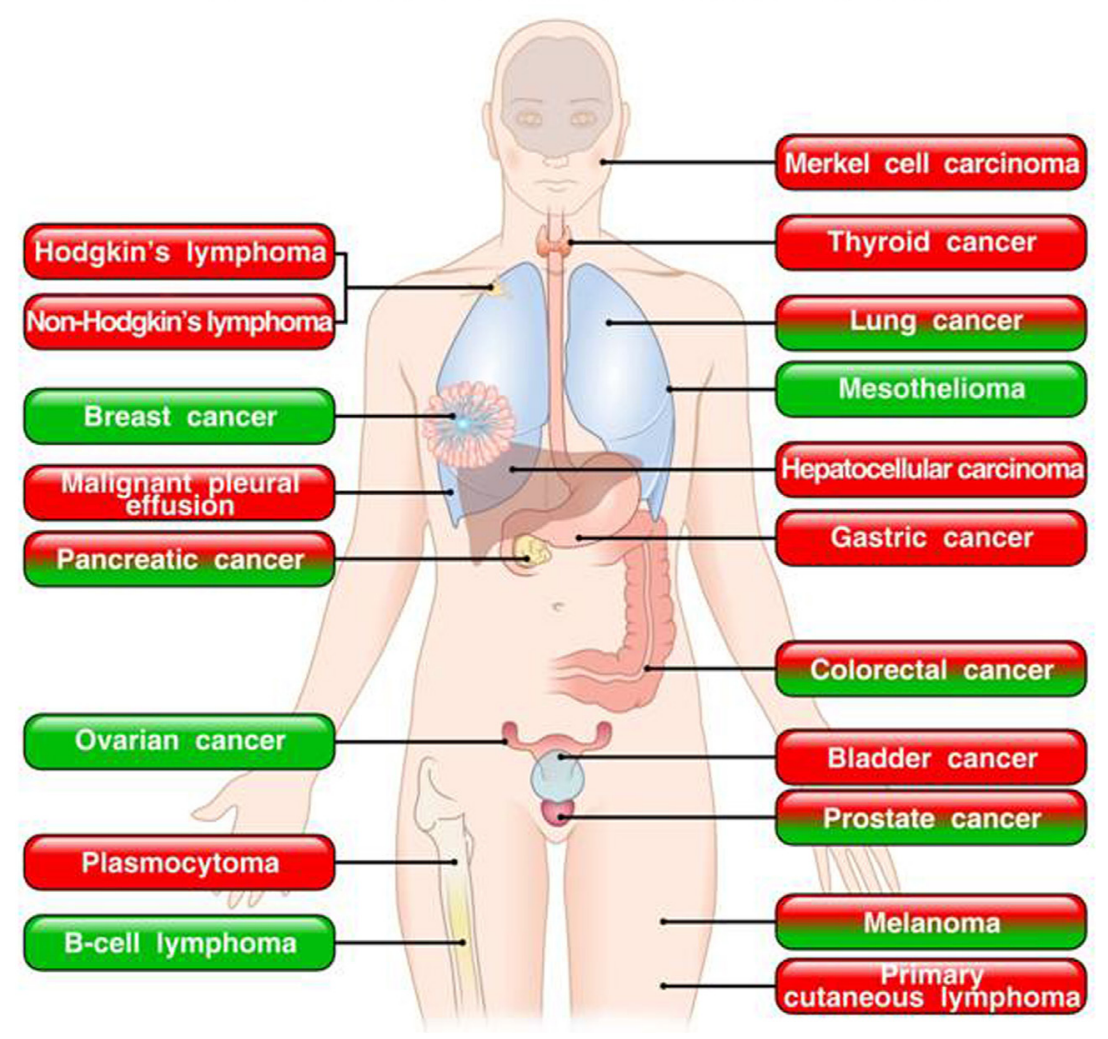

FIGURE 2 | Roles of mast cells in human tumors. In red boxes are indicated the tumors in which mast cells play a pro-tumorigenic role. In green boxes are those tumors in which mast cells appear to play a protective role. In mixed red/green boxes are presented tumors in which mast cells play both a pro- and antitumorigenic role in different studies.

Pittoni et al. found that in prostate cancer mast cells exert different functions according to tumor stage. Mast cells were pro-tumorigenic in the initial stages of prostate cancer by supplying MMP-9 in the microenvironment, but became dispensable at later stages $(40,144)$.

In stage I non-small-cell lung cancer (NSCLC), but not in stage II, peritumoral but not intratumoral mast cell (tryptase ${ }^{+}$chymase $^{+}$) density was an independent favorable prognostic factor (111).

Vascular endothelial growth factor- $\mathrm{B}$, an angiogenic factor produced by human macrophages and mast cells $(59,139)$, could play a role in early colon cancer development at the stage of adenoma formation (145).

\section{THE ROLE OF MAST CELLS IN TUMORS VARIES ACCORDING TO THEIR MICROLOCALIZATION}

The vast majority of initial studies evaluating mast cell density in different cancers did not examine differences between the periphery and the center of tumors. There is increasing evidence that different stages of tumors can be associated with qualitative and quantitative changes in different types of immune cells in the periphery and center of tumors $(146,147)$. The pro- or antitumorigenic role of mast cells in different types of melanomas remains controversial $(83,148)$. Siiskonen and collaborators found that tryptase ${ }^{+}$chymase $^{+}$mast cells in perilesional stroma of melanoma play a protective role (43). In NSCLC, mast cell infiltration of tumor islets confers a survival advantage independently of tumor stage $(113,114)$. In another study, it was found that only in stage I NSCLC increased peritumoral mast cells were associated with a better prognosis (111). In pancreatic ductal adenocarcinoma, mast cell density in the intratumoral border zone, but not the peritumoral or the intratumoral center zone, was associated with a worse prognosis (86). In prostate cancer, high intratumoral mast cell density was initially associated with good prognosis (116). Subsequently, it was reported that intratumoral mast cells inhibited tumor growth, whereas peritumoral mast cells stimulated human prostate cancer (36).

Mast cells are increased in patients with both cutaneous T-cell lymphoma and cutaneous B-cell lymphoma compared with normal skin, particularly at the periphery of the tumors. Interestingly, the density of mast cells in the center of tumors was similar to normal skin. The density of peripheral mast cells correlated with disease progression (48).

Collectively, these findings suggest that the microlocalization of mast cells is an important aspect in the initiation and progression of several tumors. 
Figure 3 schematically illustrates the mechanisms by which mast cells and some of their mediators may play a pro-tumorigenic or an antitumorigenic role.

\section{WHICH ARE THE ACTIVATORS OF TAMCs IN TUMOR MICROENVIRONMENTS?}

Peritumoral and intratumoral mast cells operate in an inflammatory microenvironment characterized by hypoxia, the accumulation of lactic acid, adenosine, $\mathrm{PGE}_{2}, \mathrm{IFN}-\gamma$, and by low $\mathrm{pH}$ (149-151). This milieu is likely to influence mast cell recruitment and activation. Mast cells can be recruited by SCF produced by several tumors and by mast cells themselves $(13,58)$. Mast cells can be recruited by VEGFs and Ang1 produced by tumor and immune cells through the engagement of VEGFR-1/VEGFR-2 and Tie2, respectively, expressed by human mast cells $(38,59,60)$.

Hypoxia, a feature of tumor microenvironment (150), activates human mast cells to release IL-6 (152) and VEGF-A (153). Adenosine, produced by tumor cells and mast cells (154), is markedly increased (150) and is an immunosuppressive factor in tumor microenvironment (13). Adenosine potentiates histamine release (155) and the production of angiogenic factors from human mast cells and macrophages $(61,139,156)$. Cyclooxygenase 2, overexpressed in tumors (150), generates $\mathrm{PGE}_{2}$ which induces angiogenic and lymphangiogenic factors from human mast cells (59). Several chemokines (CXCL1, CXCL10, and CXCL12) can activate mast cells and enhance mast cell secretion of CXCL8/IL-8 $(38,157)$. Thus, these chemokines can promote angiogenesis/ lymphangiogenesis via the recruitment of mast cells to the edge of solid tumors.

The impact of IgE-mediated activation of mast cells on tumor development and progression has been investigated (158). Monomeric IgE, in the absence of antigen, induced VEGF-A production from mast cells and increased melanoma growth (8). Increased expression of immunoglobulin free light chains (FLC) was found within stroma of various human cancers. In a murine B16F10 melanoma model, inhibition of FLC-mediated mast cell activation reduced tumor growth (12). Alarmins are upregulated in cancers (159) and can activate mast cells (160). IL-33 is upregulated in squamous cell carcinoma (SCC) (161), and mast cell activation by IL-33 occurs in skin cancers (161). IL-33 induces the production of GM-CSF, CXCL8/IL-8, and VEGF-A from mast cells $(128,162,163)$. In addition to the high-affinity receptor for IgE (FceRI), human mast cells express the IgG receptors Fc $\gamma$ RIIA and Fc $\gamma$ RI $(164,165)$. Fc $\gamma$ RI is upregulated by IFN- $\gamma$ which is

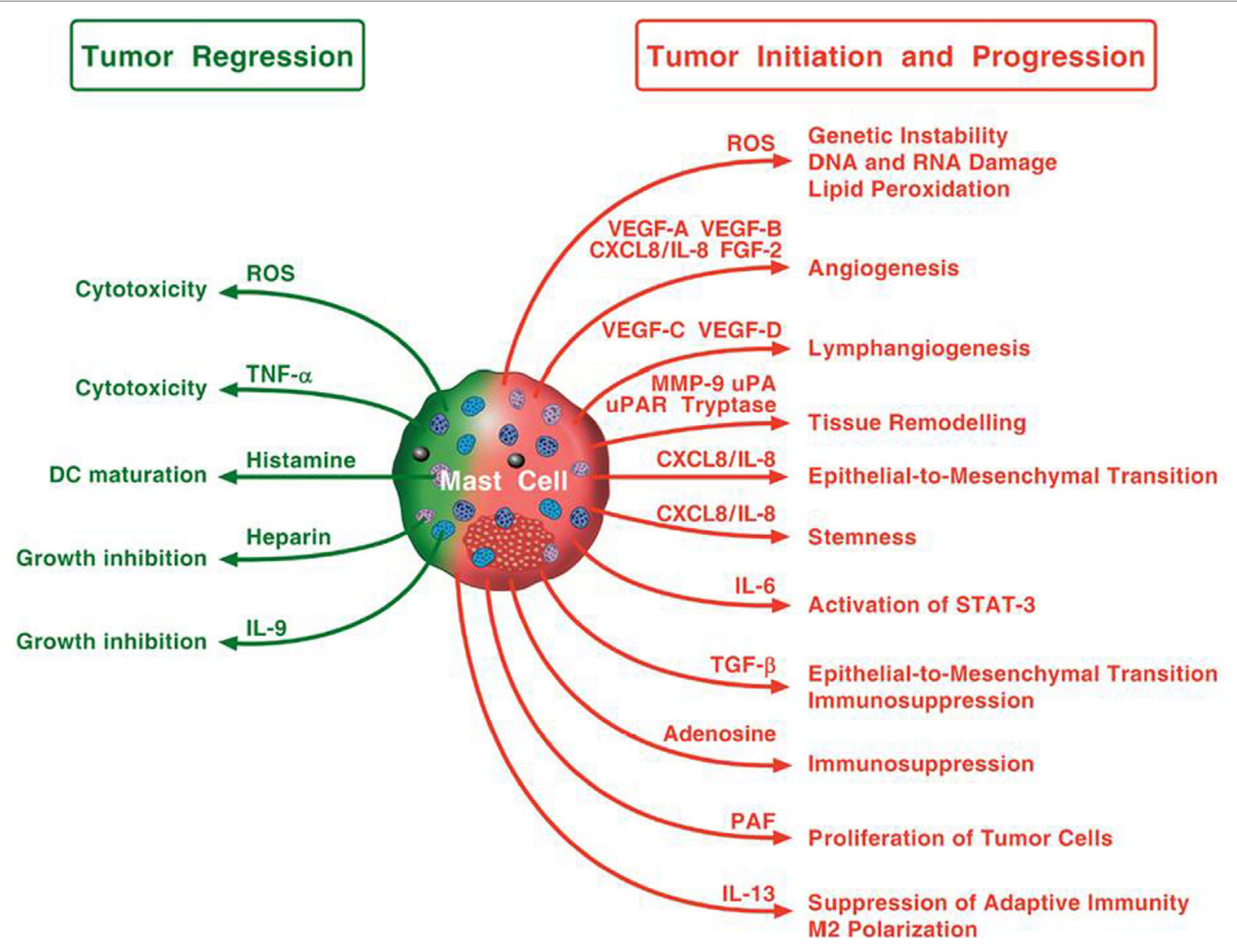

FIGURE 3 | Possible mechanisms by which mast cells and their mediators may play a pro-tumorigenic or an antitumorigenic role. Mast cells in tumor microenvironment can promote tumor initiation and progression through the release of ROS, angiogenic and lymphangiogenic factors, and proteases, the induction of epithelial-to-mesenchymal transition and stemness. Mast cells can also activate STAT-3, contribute to immunosuppression and macrophage M2 polarization, and stimulate proliferation of tumor cells. Mast cells can exhibit antitumor activity through direct tumor cell cytotoxicity mediated by ROS and TNF- $\alpha$ or indirectly through the release of heparin, IL-9, and stimulation of dendritic cell maturation. 
highly expressed in tumors. In the tumor microenvironment, antitumor IgG immune complexes may activate mast cells (166). OP, upregulated in human cancer (167), is produced by mast cells (66) and induces their migration and degranulation $(35,66)$. Platelet-activating factor, produced by human mast cells (168), upregulates CXCR4 on mast cells and promotes their migration to lymph nodes $(169,170)$.

In summary, a plethora of immunologic and non-immunologic factors present in tumor microenvironment can activate TAMCs.

\section{MAST CELLS AS A POTENTIAL THERAPEUTIC TARGET IN CANCER}

Several therapeutic strategies have been envisioned to limit tumor growth by targeting mast cells and their mediators. Mast cells play a pro-tumorigenic role in human bladder cancer through stimulating estrogen receptor $\beta(\operatorname{ER} \beta)$ (67). In a murine model of bladder cancer, these authors showed that a selective ER $\beta$ antagonist inhibited mast cell-promoted tumor growth. It has been found that mast cells can promote the proliferation of colon cancer in vivo (71). Injection of Fce-PE40 chimeric toxin, which induced mast cell apoptosis, inhibited colon tumor development in vivo.

Pharmacologic inhibition of mast cell degranulation by cromolyn inhibited Myc-induced pancreatic islet tumors (94), experimental pancreatic and thyroid cancer $(37,38,95)$, and cholangiocarcinoma (46).

Pittoni and collaborators have demonstrated that pharmacologic inhibition by cromolyn and genetic ablation of mast cells inhibited prostate cancer in mice (40). However, mast cells protect from a malignant neuroendocrine tumor. It has been shown that mast cells can promote prostate cancer chemotherapy and radiotherapy resistance via modulation of $\mathrm{p} 38 / \mathrm{p} 53 / \mathrm{p} 21$. The authors suggested that targeting these signaling pathways may help to suppress chemo- and radiotherapy resistance in prostate cancer (97). In a mouse model, mast cells enhanced prostate cancer growth via modulation of androgen receptor and increasing MMP-9 expression (87). The authors suggested that targeting these mast cell-androgen receptor signals may inhibit tumor growth.

The UV wavelengths in sunlight are the prime etiological cause of skin cancers, including basal cell carcinoma and SCC. Exposure to UV affects skin mast cell migration by altering the CXCR4-CXCL12 axis (99). The pharmacological blockage of the CXCR4-CXCL12 pathway inhibited sunlight-induced skin cancer.

Collectively, these findings indicate that mast cells and their mediators deserve focused consideration as therapeutic targets in different types of cancer.

\section{OUTSTANDING QUESTIONS}

There is compelling evidence that human mast cells isolated from various anatomical sites respond to different stimuli and release distinct mediators $(14,59,160,166,171)$. Peritumoral and intratumoral TAMCs are embedded by a wide spectrum of mediators and in close contact with several stromal cells. It will be important to identify the stimuli that can activate TAMCs in different tumor microenvironments. Similarly, it will be important to identify preformed and de novo synthesized mediators released in situ by TAMCs.

Studies on mast cell biology are routinely conducted at physiological pH and normoxia. By contrast, the metabolic phenotype of tumors is characterized by low $\mathrm{pH}$ and areas of either hypoxia or normoxia (150). Tumor-associated macrophages in normoxic tumor tissues express M1 markers, whereas those in hypoxic tumor tissues preferentially express M2 markers (172). These findings caution against the over interpretation of results from studies of whole TAMC populations. It will be of fundamental importance to investigate how hypoxic conditions and metabolism activate/modulate the production of pro-inflammatory and angiogenic/lymphangiogenic factors from TAMCs. Proteomic (173) and lipidomic analyses (174) of mast cells will help to characterize the proangiogenic and antitumorigenic profiles of TAMCs from different human tumors.

Analysis of mast cells in draining lymph nodes and in ectopic lymphoid structures of tumors has only recently begun $(35,43)$. The role of mast cells in draining lymph nodes, in tertiary lymphoid tissues, and at metastatic sites of different tumors remains to be explored.

IgE has been suggested to play a protective role in tumor growth $(21,158)$. Additional studies should investigate the role, if any, of IgE-mediated activation of mast cells in different human tumors.

The pro- or antitumorigenic role(s) of mast cells in different human tumors appears to be generally, but not always, cancer specific. We cannot exclude the possibility that subpopulation of TAMCs could play different, even opposite effects in various types/subtypes of tumors.

There is preliminary evidence that peritumoral mast cells (48) play different roles compared to intratumoral mast cells (36, $113,114)$. Studies in other experimental and human tumors will clarify whether the microlocalization of mast cells can markedly influence their effects.

Within the last years, gene expression profiling has demonstrated that several individual human cancers (e.g., melanoma, gastric, lung, and breast cancers) are heterogeneous with a spectrum of molecular changes $(83,175-178)$. The complex heterogeneity (spatial, temporal, intratumor, intertumor) of the tumor microenvironment adds an additional layer of complexity $(179,180)$. An important task will be to correlate the role of TAMCs in different subtypes of human cancers as defined by genetic markers.

There is recent evidence in melanoma (43), in prostate (40), and in pancreatic cancer (37) that mast cells can play different roles in early and late phases of tumor initiation and growth. This fascinating hypothesis deserves to be further investigated in order to clarify the functional role of TAMCs in the progression of experimental and human cancers.

Two strains of mast cell-deficient mice with mutations affecting Kit, $\mathrm{Kit}^{\mathrm{W} / \mathrm{w}-\mathrm{v}}(90,91,94,98,101,104)$ and $\mathrm{Kit}^{\mathrm{W}-\mathrm{sh} / \mathrm{W}-\mathrm{sh}}$ $(14,35,40,85,89)$, have been extensively used to study the role of mast cells in tumor growth. These mice are profoundly deficient in mast cells and also exhibit several other abnormalities, such as basophil deficiency $(181,182)$. Recent evidence suggests that basophils can play a role in human pancreatic cancer (183). New 
Kit-independent mast cell-deficient mice (184) have been used to evaluate the role of mast cells in cutaneous lymphoma (48), malignant pleural effusion (35), and skin cancerogenesis (118). Collectively, results obtained with mast cell-deficient mouse models should be interpreted with caution because even new mouse mutants with unperturbed Kit function also showed some hematological abnormalities $(184,185)$.

Mast cells are plastic cells: their phenotype depends on their anatomical location and the physiological or pathological context $(4,5,171)$. TAMCs are exposed in a hostile tumor environment to increased levels of lactate, $\mathrm{PGE}_{2}$, adenosine, IFN- $\gamma$, and a low $\mathrm{pH}(149,150)$. This metabolic milieu can profoundly alter mast cell behavior. It has been shown that it is possible to reverse the immunosuppressive and pro-tumoral properties of tumorassociated macrophages $(186,187)$. A better knowledge of the pro-tumorigenic profile of TAMCs could help to "re-educate" these cells to play an antitumorigenic role.

Tumor cells evade host immune attack by expressing several checkpoint inhibitors, such as programmed cell death-1 (PD-1) ligands (PD-L1 and PD-L2) which inhibit PD- $1^{+}$lymphocytes in tumor microenvironment (188). Monoclonal antibodies targeting the PD-1/PD-L1 pathway unleash antitumor immunity and have revolutionized the management of a wide spectrum of malignancies (189). Certain cancer cells (e.g., melanoma) express also PD-1, in addition to $\mathrm{PD}-\mathrm{L} 1$, providing an additional tumor intrinsic mechanism enhancing the pro-tumorigenic effect of PD-1/PD-L1 axis (190). Mouse mast cells highly express PD-L1 and, to a lesser extent, PD-L2 (191). An important task will be to investigate the role of $\mathrm{PD}-\mathrm{L}^{+}{ }^{+} \mathrm{TAMC}$ in tumor microenvironment.

All the above implies that elucidation of the roles of mast cells in different human tumors will demand studies of increasing complexity beyond those assessing merely mast cell density and microlocalization.

\section{REFERENCES}

1. Ehrlich P. Beiträge zur Kenntniss der granulirten Bindegewebszellen und der eosinophilen Leukocythen. Arch Anat Physiol (Leipzig) (1879) 3:166-9.

2. Ehrlich P. Über die specifischen Granulationen des Blutes. Arch Anat Physiol (Leipzig) (1879):571-9.

3. Mulero I, Sepulcre MP, Meseguer J, Garcia-Ayala A, Mulero V. Histamine is stored in mast cells of most evolutionarily advanced fish and regulates the fish inflammatory response. Proc Natl Acad Sci U S A (2007) 104:19434-9. doi:10.1073/pnas.0704535104

4. Marone G, Galli SJ, Kitamura Y. Probing the roles of mast cells and basophils in natural and acquired immunity, physiology and disease. Trends Immunol (2002) 23:425-7. doi:10.1016/S1471-4906(02)02274-3

5. Galli SJ, Tsai M. IgE and mast cells in allergic disease. Nat Med (2012) 18:693-704. doi:10.1038/nm.2755

6. Kirshenbaum AS, Goff JP, Semere T, Foster B, Scott LM, Metcalfe DD. Demonstration that human mast cells arise from a progenitor cell population that is CD34(+), c-kit(+), and expresses aminopeptidase N (CD13). Blood (1999) 94:2333-42.

7. Krystel-Whittemore M, Dileepan KN, Wood JG. Mast cell: a multi-functional master cell. Front Immunol (2016) 6:620. doi:10.3389/fimmu.2015.00620

8. Jimenez-Andrade GY, Ibarra-Sanchez A, Gonzalez D, Lamas M, GonzalezEspinosa C. Immunoglobulin E induces VEGF production in mast cells and potentiates their pro-tumorigenic actions through a Fyn kinase-dependent mechanism. J Hematol Oncol (2013) 6:56. doi:10.1186/1756-8722-6-56

\section{CONCLUSION}

In several human and experimental tumors, mast cells and their mediators play a pro-tumorigenic role. However, in other tumors and even in the same tumor, mast cells seem to play a protective role. These apparently controversial results might reflect differences in stage, grade, and subtypes of tumors, different methods to identify mast cells (e.g., tryptase ${ }^{+}$, chymase ${ }^{+}$, toluidine blue, $\mathrm{CD} 117^{+}$, Giemsa), or different microanatomical compartment (i.e., peritumoral vs intratumoral) analyzed in the various studies. Whatever the mechanisms, there are many unanswered questions that need to be addressed before we understand whether mast cells are an ally, adversary, or innocent bystander in human cancers.

\section{AUTHOR CONTRIBUTIONS}

GV, MG, and SL conceived and designed the review. All the authors contributed intellectually and to the writing of the submitted version of the manuscript.

\section{ACKNOWLEDGMENTS}

The authors apologize to the many authors who have contributed importantly to this field and whose work has not been cited due to space and citation restrictions. The authors thank Fabrizio Fiorbianco for preparing the figures and Clarice Castaldo for excellent secretarial help. GM is the recipient of the 2016 Palasciano Award.

\section{FUNDING}

This work was supported in part by grants from Regione Campania CISI-Lab Project, CRèME Project, and TIMING Project.

9. Genovese A, Borgia G, Bjorck L, Petraroli A, de Paulis A, Piazza M, et al. Immunoglobulin superantigen protein Linduces IL-4 and IL-13 secretion from human Fc epsilon RI+ cells through interaction with the kappa light chains of IgE. J Immunol (2003) 170:1854-61. doi:10.4049/jimmunol.170.4.1854

10. Marone G, Rossi FW, Detoraki A, Granata F, Marone GC, Genovese A, et al. Role of superallergens in allergic disorders. In: Marone G, editor. Superantigens and Superallergens. Basel: Karger (2007). 195 p.

11. Andreu P, Johansson M, Affara NI, Pucci F, Tan T, Junankar S, et al. FcRgamma activation regulates inflammation-associated squamous carcinogenesis. Cancer Cell (2010) 17:121-34. doi:10.1016/j.ccr.2009.12.019

12. Groot Kormelink T, Powe DG, Kuijpers SA, Abudukelimu A, Fens MH, Pieters EH, et al. Immunoglobulin free light chains are biomarkers of poor prognosis in basal-like breast cancer and are potential targets in tumor-associated inflammation. Oncotarget (2014) 5:3159-67. doi:10.18632/oncotarget.1868

13. Huang B, Lei Z, Zhang GM, Li D, Song C, Li B, et al. SCF-mediated mast cell infiltration and activation exacerbate the inflammation and immunosuppression in tumor microenvironment. Blood (2008) 112:1269-79. doi:10.1182/ blood-2008-03-147033

14. Oldford SA, Haidl ID, Howatt MA, Leiva CA, Johnston B, Marshall JS. A critical role for mast cells and mast cell-derived IL-6 in TLR2-mediated inhibition of tumor growth. J Immunol (2010) 185:7067-76. doi:10.4049/jimmunol.1001137

15. Borriello F, Iannone R, Marone G. Histamine release from mast cells and basophils. Handb Exp Pharmacol (2017) 1-19. doi:10.1007/164_2017_18

16. Marichal T, Starkl P, Reber LL, Kalesnikoff J, Oettgen HC, Tsai M, et al. A beneficial role for immunoglobulin $\mathrm{E}$ in host defense against honeybee venom. Immunity (2013) 39:963-75. doi:10.1016/j.immuni.2013.10.005 
17. Palm NW, Rosenstein RK, Yu S, Schenten DD, Florsheim E, Medzhitov R. Bee venomphospholipase $\mathrm{A} 2$ inducesaprimarytype 2 responsethatisdependenton the receptorST2 and confersprotectiveimmunity.Immunity (2013) 39:976-85. doi:10.1016/j.immuni.2013.10.006

18. Wang Z, Lai Y, Bernard JJ, Macleod DT, Cogen AL, Moss B, et al. Skin mast cells protect mice against vaccinia virus by triggering mast cell receptor S1PR2 and releasing antimicrobial peptides. J Immunol (2012) 188:345-57. doi:10.4049/jimmunol.1101703

19. Chan CY, St John AL, Abraham SN. Plasticity in mast cell responses during bacterial infections. Curr Opin Microbiol (2012) 15:78-84. doi:10.1016/j.mib.2011.10.007

20. Josephs DH, Spicer JF, Corrigan CJ, Gould HJ, Karagiannis SN. Epidemiological associations of allergy, IgE and cancer. Clin Exp Allergy (2013) 43:1110-23. doi:10.1111/cea.12178

21. Jensen-Jarolim E, Bax HJ, Bianchini R, Capron M, Corrigan C, Castells M, et al. AllergoOncology - the impact of allergy in oncology: EAACI position paper. Allergy (2016). doi:10.1111/all.13119

22. Platzer B, Elpek KG, Cremasco V, Baker K, Stout MM, Schultz C, et al. IgE/ FcepsilonRI-mediated antigen cross-presentation by dendritic cells enhances anti-tumor immune responses. Cell Rep (2015) 10:1487-95. doi:10.1016/j. celrep.2015.02.015

23. Dawson MA, Kouzarides T, Huntly BJ. Targeting epigenetic readers in cancer. N Engl J Med (2012) 367:647-57. doi:10.1056/NEJMra1112635

24. Zitvogel L, Apetoh L, Ghiringhelli F, Andre F, Tesniere A, Kroemer G. The anticancer immune response: indispensable for therapeutic success? J Clin Invest (2008) 118:1991-2001. doi:10.1172/JCI35180

25. Zitvogel L, Galluzzi L, Smyth MJ, Kroemer G. Mechanism of action of conventional and targeted anticancer therapies: reinstating immunosurveillance. Immunity (2013) 39:74-88. doi:10.1016/j.immuni.2013.06.014

26. Bissell MJ, Hines WC. Why don't we get more cancer? A proposed role of the microenvironment in restraining cancer progression. Nat Med (2011) 17:320-9. doi:10.1038/nm.2328

27. Hanahan D, Coussens LM. Accessories to the crime: functions of cells recruited to the tumor microenvironment. Cancer Cell (2012) 21:309-22. doi:10.1016/j.ccr.2012.02.022

28. Mantovani A, Allavena P, Sica A, Balkwill F. Cancer-related inflammation. Nature (2008) 454:436-44. doi:10.1038/nature07205

29. Galdiero MR, Garlanda C, Jaillon S, Marone G, Mantovani A. Tumor associated macrophages and neutrophils in tumor progression. J Cell Physiol (2013) 228:1404-12. doi:10.1002/jcp.24260

30. Galdiero MR, Marone G, Mantovani A. Cancer inflammation and cytokines. Perspect Biol (2017). (in press).

31. Westphal E. Über Mastzellen. In: Ehrlich P, editor. Farbenanalytische Untersuchungen. Berlin: Hirschwald (1891). p. 17-41.

32. Aoki M, Pawankar R, Niimi Y, Kawana S. Mast cells in basal cell carcinoma express VEGF, IL-8 and RANTES. Int Arch Allergy Immunol (2003) 130:216-23. doi:10.1159/000069515

33. Beer TW, Ng LB, Murray K. Mast cells have prognostic value in Merkel cell carcinoma. Am JDermatopathol (2008) 30:27-30. doi:10.1097/ DAD.0b013e31815c932a

34. Dvorak AM, Mihm MC Jr, Osage JE, Dvorak HF. Melanoma. An ultrastructural study of the host inflammatory and vascular responses. J Invest Dermatol (1980) 75:388-93. doi:10.1111/1523-1747.ep12523627

35. Giannou AD, Marazioti A, Spella M, Kanellakis NI, Apostolopoulou H, Psallidas I, et al. Mast cells mediate malignant pleural effusion formation. J Clin Invest (2015) 125:2317-34. doi:10.1172/JCI79840

36. Johansson A, Rudolfsson S, Hammarsten P, Halin S, Pietras K, Jones J, et al. Mast cells are novel independent prognostic markers in prostate cancer and represent a target for therapy.AmJ Pathol (2010) 177:1031-41. doi:10.2353/ajpath.2010.100070

37. Ma Y, Hwang RF, Logsdon CD, Ullrich SE. Dynamic mast cell-stromal cell interactions promote growth of pancreatic cancer. Cancer Res (2013) 73:3927-37. doi:10.1158/0008-5472.CAN-12-4479

38. Melillo RM, Guarino V, Avilla E, Galdiero MR, Liotti F, Prevete N, et al. Mast cells have a protumorigenic role in human thyroid cancer. Oncogene (2010) 29:6203-15. doi:10.1038/onc.2010.348

39. Ng L, Beer TW, Murray K. Vascular density has prognostic value in Merkel cell carcinoma. Am J Dermatopathol (2008) 30:442-5. doi:10.1097/ DAD.0b013e318172364d

40. Pittoni P, Tripodo C, Piconese S, Mauri G, Parenza M, Rigoni A, et al. Mast cell targeting hampers prostate adenocarcinoma development but promotes the occurrence of highly malignant neuroendocrine cancers. Cancer Res (2011) 71:5987-97. doi:10.1158/0008-5472.CAN-11-1637

41. Ribatti D, Ennas MG, Vacca A, Ferreli F, Nico B, Orru S, et al. Tumor vascularity and tryptase-positive mast cells correlate with a poor prognosis in melanoma. Eur J Clin Invest (2003) 33:420-5. doi:10.1046/j.1365-2362.2003.01152.x

42. Ribatti D, Vacca A, Ria R, Marzullo A, Nico B, Filotico R, et al. Neovascularisation, expression of fibroblast growth factor-2, and mast cells with tryptase activity increase simultaneously with pathological progression in human malignant melanoma. Eur J Cancer (2003) 39:666-74. doi:10.1016/ S0959-8049(02)00150-8

43. Siiskonen H, Poukka M, Bykachev A, Tyynela-Korhonen K, Sironen R, Pasonen-Seppanen S, et al. Low numbers of tryptase+ and chymase+ mast cells associated with reduced survival and advanced tumor stage in melanoma. Melanoma Res (2015) 25:479-85. doi:10.1097/CMR.0000000000000192

44. Takahashi K, Mulliken JB, Kozakewich HP, Rogers RA, Folkman J, Ezekowitz RA. Cellular markers that distinguish the phases of hemangioma during infancy and childhood. J Clin Invest (1994) 93:2357-64. doi:10.1172/ JCI117241

45. Toth-Jakatics R, Jimi S, Takebayashi S, Kawamoto N. Cutaneous malignant melanoma: correlation between neovascularization and peritumor accumulation of mast cells overexpressing vascular endothelial growth factor. Hum Pathol (2000) 31:955-60. doi:10.1053/hupa.2000.16658

46. Johnson C, Huynh V, Hargrove L, Kennedy L, Graf-Eaton A, Owens J, et al. Inhibition of mast cell-derived histamine decreases human cholangiocarcinoma growth and differentiation via c-kit/stem cell factor-dependent signaling. Am J Pathol (2016) 186:123-33. doi:10.1016/j.ajpath.2015.09.016

47. Ribatti D, Vacca A, Nico B, Quondamatteo F, Ria R, Minischetti M, et al Bone marrow angiogenesis and mast cell density increase simultaneously with progression of human multiple myeloma. Br J Cancer (1999) 79:451-5. doi:10.1038/sj.bjc.6690070

48. Rabenhorst A, Schlaak M, Heukamp LC, Forster A, Theurich S, von BergweltBaildon M, et al. Mast cells play a protumorigenic role in primary cutaneous lymphoma. Blood (2012) 120:2042-54. doi:10.1182/blood-2012-03-415638

49. Vyzoukaki R, Tsirakis G, Pappa CA, Devetzoglou M, Tzardi M, Alexandrakis MG. The impact of mast cell density on the progression of bone disease in multiple myeloma patients. Int Arch Allergy Immunol (2015) 168:263-8. doi:10.1159/000443275

50. Tripodo C, Gri G, Piccaluga PP, Frossi B, Guarnotta C, Piconese S, et al. Mast cells and Th17 cells contribute to the lymphoma-associated pro-inflammatory microenvironment of angioimmunoblastic T-cell lymphoma. Am J Pathol (2010) 177:792-802. doi:10.2353/ajpath.2010.091286

51. Taskinen M, Karjalainen-Lindsberg ML, Leppa S. Prognostic influence of tumor-infiltrating mast cells in patients with follicular lymphoma treated with rituximab and CHOP. Blood (2008) 111:4664-7. doi:10.1182/ blood-2007-11-125823

52. Franco G, Guarnotta C, Frossi B, Piccaluga PP, Boveri E, Gulino A, et al. Bone marrow stroma CD40 expression correlates with inflammatory mast cell infiltration and disease progression in splenic marginal zone lymphoma. Blood (2014) 123:1836-49. doi:10.1182/blood-2013-04-497271

53. Molin D, Edstrom A, Glimelius I, Glimelius B, Nilsson G, Sundstrom C, et al. Mast cell infiltration correlates with poor prognosis in Hodgkin's lymphoma. Br J Haematol (2002) 119:122-4. doi:10.1046/j.1365-2141.2002.03768.x

54. Andersen MD, Kamper P, Nielsen PS, Bendix K, Riber-Hansen R, Steiniche T, et al. Tumour-associated mast cells in classical Hodgkin's lymphoma: correlation with histological subtype, other tumour-infiltrating inflammatory cell subsets and outcome. Eur J Haematol (2016) 96:252-9. doi:10.1111/ejh.12583

55. Englund A, Molin D, Enblad G, Karlen J, Glimelius I, Ljungman G, et al. The role of tumour-infiltrating eosinophils, mast cells and macrophages in classical and nodular lymphocyte predominant Hodgkin lymphoma in children. Eur J Haematol (2016) 97:430-8. doi:10.1111/ejh.12747

56. Marone G, Varricchi G, Loffredo S, Granata F. Mast cells and basophils in inflammatory and tumor angiogenesis and lymphangiogenesis. Eur J Pharmacol (2016) 778:146-51. doi:10.1016/j.ejphar.2015.03.088

57. Yamamoto T, Katayama I, Nishioka K. Expression of stem cell factor in basal cell carcinoma. Br JDermatol (1997) 137:709-13. doi:10.1046/j.1365-2133.1997.19402055.x

58. de Paulis A, Minopoli G, Arbustini E, de Crescenzo G, Dal Piaz F, Pucci P, et al. Stem cell factor is localized in, released from, and cleaved by human mast cells. J Immunol (1999) 163:2799-808. 
59. Detoraki A, Staiano RI, Granata F, Giannattasio G, Prevete N, de Paulis A, et al. Vascular endothelial growth factors synthesized by human lung mast cells exert angiogenic effects. J Allergy Clin Immunol (2009) 123:1142-9, 1149.e1141-1145. doi:10.1016/j.jaci.2009.01.044

60. Prevete N, Staiano RI, Granata F, Detoraki A, Necchi V, Ricci V, et al. Expression and function of angiopoietins and their tie receptors in human basophils and mast cells. J Biol Regul Homeost Agents (2013) 27:827-39.

61. Visciano C, Liotti F, Prevete N, Cali G, Franco R, Collina F, et al. Mast cells induce epithelial-to-mesenchymal transition and stem cell features in human thyroid cancer cells through an IL-8-Akt-Slug pathway. Oncogene (2015) 34:5175-86. doi:10.1038/onc.2014.441

62. Kay LJ, Yeo WW, Peachell PT. Prostaglandin E2 activates EP2 receptors to inhibit human lung mast cell degranulation. Br J Pharmacol (2006) 147:707-13. doi:10.1038/sj.bjp.0706664

63. Weller CL, Collington SJ, Hartnell A, Conroy DM, Kaise T, Barker JE, et al. Chemotactic action of prostaglandin E2 on mouse mast cells acting via the PGE2 receptor 3. Proc Natl Acad Sci U S A (2007) 104:11712-7. doi:10.1073/ pnas.0701700104

64. Godot V, Arock M, Garcia G, Capel F, Flys C, Dy M, et al. H4 histamine receptor mediates optimal migration of mast cell precursors to CXCL12. J Allergy Clin Immunol (2007) 120:827-34. doi:10.1016/j.jaci.2007.05.046

65. Weller CL, Collington SJ, Brown JK, Miller HR, Al-Kashi A, Clark P, et al. Leukotriene B4, an activation product of mast cells, is a chemoattractant for their progenitors. J Exp Med (2005) 201:1961-71. doi:10.1084/jem.20042407

66. Nagasaka A, Matsue H, Matsushima H, Aoki R, Nakamura Y, Kambe N, et al. Osteopontin is produced by mast cells and affects IgEmediated degranulation and migration of mast cells. Eur J Immunol (2008) 38:489-99. doi:10.1002/eji.200737057

67. Rao Q, Chen Y, Yeh CR, Ding J, Li L, Chang C, et al. Recruited mast cells in the tumor microenvironment enhance bladder cancer metastasis via modulation of ERbeta/CCL2/CCR2 EMT/MMP9 signals. Oncotarget (2016) 7:7842-55. doi:10.18632/oncotarget.5467

68. Acikalin MF, Oner U, Topcu I, Yasar B, Kiper H, Colak E. Tumour angiogenesis and mast cell density in the prognostic assessment of colorectal carcinomas. Dig Liver Dis (2005) 37:162-9. doi:10.1016/j.dld.2004.09.028

69. Gulubova M, Vlaykova T. Prognostic significance of mast cell number and microvascular density for the survival of patients with primary colorectal cancer. J Gastroenterol Hepatol(2009)24:1265-75.doi:10.1111/j.1440-1746.2007.05009.x

70. Ammendola M, Sacco R, Sammarco G, Donato G, Montemurro S, Ruggieri E, et al. Correlation between serum tryptase, mast cells positive to tryptase and microvascular density in colo-rectal cancer patients: possible biological-clinical significance. PLoS One (2014) 9:e99512. doi:10.1371/ journal.pone.0099512

71. Wang S, Li L, Shi R, Liu X, Zhang J, Zou Z, et al. Mast cell targeted chimeric toxin can be developed as an adjunctive therapy in colon cancer treatment. Toxins (Basel) (2016) 8:1-18. doi:10.3390/toxins 8030071

72. Malfettone A, Silvestris N, Saponaro C, Ranieri G, Russo A, Caruso S, et al. High density of tryptase-positive mast cells in human colorectal cancer: a poor prognostic factor related to protease-activated receptor 2 expression. J Cell Mol Med (2013) 17:1025-37. doi:10.1111/jcmm.12073

73. Suzuki S, Ichikawa Y, Nakagawa K, Kumamoto T, Mori R, Matsuyama R, et al. High infiltration of mast cells positive to tryptase predicts worse outcome following resection of colorectal liver metastases. BMC Cancer (2015) 15:840. doi:10.1186/s12885-015-1863-z

74. Fakhrjou A, Niroumand-Oscoei SM, Somi MH, Ghojazadeh M, Naghashi S, Samankan S. Prognostic value of tumor-infiltrating mast cells in outcome of patients with esophagus squamous cell carcinoma. J Gastrointest Cancer (2014) 45:48-53. doi:10.1007/s12029-013-9550-2

75. Yano H, Kinuta M, Tateishi H, Nakano Y, Matsui S, Monden T, et al. Mast cell infiltration around gastric cancer cells correlates with tumor angiogenesis and metastasis. Gastric Cancer (1999) 2:26-32. doi:10.1007/s101200050017

76. Kondo K, Muramatsu M, Okamoto Y, Jin D, Takai S, Tanigawa N, et al. Expression of chymase-positive cells in gastric cancer and its correlation with the angiogenesis. J Surg Oncol (2006) 93:36-42; discussion 42-33. doi:10.1002/jso.20394

77. Ammendola M, Sacco R, Donato G, Zuccala V, Russo E, Luposella M, et al. Mast cell positivity to tryptase correlates with metastatic lymph nodes in gastrointestinal cancer patients treated surgically. Oncology (2013) 85:111-6. doi:10.1159/000351145
78. Ammendola M, Marech I, Sammarco G, Zuccala V, Luposella M, Zizzo N, et al. Infiltrating mast cells correlate with angiogenesis in bone metastases from gastric cancer patients. Int J Mol Sci (2015) 16:3237-50. doi:10.3390/ijms16023237

79. Tu JF, Pan HY, Ying XH, Lou J, Ji JS, Zou H. Mast cells comprise the major of interleukin 17-producing cells and predict a poor prognosis in hepatocellular carcinoma. Medicine (Baltimore) (2016) 95:e3220. doi:10.1097/ MD.0000000000003220

80. Imada A, Shijubo N, Kojima H, Abe S. Mast cells correlate with angiogenesis and poor outcome in stage I lung adenocarcinoma. Eur Respir J (2000) 15:1087-93. doi:10.1034/j.1399-3003.2000.01517.x

81. Takanami I, Takeuchi K, Naruke M. Mast cell density is associated with angiogenesis and poor prognosis in pulmonary adenocarcinoma. Cancer (2000) 88:2686-92. doi:10.1002/1097-0142(20000615)88:12<2686::AIDCNCR6>3.3.CO;2-Y

82. Banat GA, Tretyn A, Pullamsetti SS, Wilhelm J, Weigert A, Olesch C, et al. Immune and inflammatory cell composition of human lung cancer stroma. PLoS One (2015) 10:e0139073. doi:10.1371/journal.pone.0139073

83. Holzel M, Landsberg J, Glodde N, Bald T, Rogava M, Riesenberg S, et al. A preclinical model of malignant peripheral nerve sheath tumor-like melanoma is characterized by infiltrating mast cells. Cancer Res (2016) 76:251-63. doi:10.1158/0008-5472.CAN-15-1090

84. Strouch MJ, Cheon EC, Salabat MR, Krantz SB, Gounaris E, Melstrom LG, et al. Crosstalk between mast cells and pancreatic cancer cells contributes to pancreatic tumor progression. Clin Cancer Res (2010) 16:2257-65. doi:10.1158/1078-0432.CCR-09-1230

85. Chang DZ, Ma Y, Ji B, Wang H, Deng D, Liu Y, et al. Mast cells in tumor microenvironment promotes the in vivo growth of pancreatic ductal adenocarcinoma. Clin Cancer Res (2011) 17:7015-23. doi:10.1158/1078-0432. CCR-11-0607

86. Cai SW, Yang SZ, Gao J, Pan K, Chen JY, Wang YL, et al. Prognostic significance of mast cell count following curative resection for pancreatic ductal adenocarcinoma. Surgery (2011) 149:576-84. doi:10.1016/j.surg.2010.10.009

87. Li L, Dang Q, Xie H, Yang Z, He D, Liang L, et al. Infiltrating mast cells enhance prostate cancer invasion via altering LncRNA-HOTAIR/PRC2androgen receptor (AR)-MMP9 signals and increased stem/progenitor cell population. Oncotarget (2015) 6:14179-90. doi:10.18632/oncotarget.3651

88. Nonomura N, Takayama H, Nishimura K, Oka D, Nakai Y, Shiba M, et al. Decreased number of mast cells infiltrating into needle biopsy specimens leads to a better prognosis of prostate cancer. Br J Cancer (2007) 97:952-6. doi:10.1038/sj.bjc.6603962

89. WasiukA, Dalton DK, Schpero WL, Stan RV, Conejo-Garcia JR, Noelle RJ. Mast cells impair the development of protective anti-tumor immunity. Cancer Immunol Immunother (2012) 61:2273-82. doi:10.1007/s00262-012-1276-7

90. Wedemeyer J, Galli SJ. Decreased susceptibility of mast cell-deficient Kit(W)/ $\mathrm{Kit}(\mathrm{W}$-v) mice to the development of 1, 2-dimethylhydrazine-induced intestinal tumors. Lab Invest (2005) 85:388-96. doi:10.1038/labinvest.3700232

91. Gounaris E, Erdman SE, Restaino C, Gurish MF, Friend DS, Gounari F, et al. Mast cells are an essential hematopoietic component for polyp development. Proc Natl Acad Sci US A (2007) 104:19977-82. doi:10.1073/pnas.0704620104

92. Nordlund JJ, Askenase PW. The effect of histamine, antihistamines, and a mast cell stabilizer on the growth of cloudman melanoma cells in DBA/2 mice. J Invest Dermatol (1983) 81:28-31. doi:10.1111/1523-1747.ep12538356

93. Jeong HJ, Oh HA, Nam SY, Han NR, Kim YS, Kim JH, et al. The critical role of mast cell-derived hypoxia-inducible factor-1alpha in human and mice melanoma growth. Int J Cancer (2013) 132:2492-501. doi:10.1002/ijc.27937

94. Soucek L, Lawlor ER, Soto D, Shchors K, Swigart LB, Evan GI. Mast cells are required for angiogenesis and macroscopic expansion of Myc-induced pancreatic islet tumors. Nat Med (2007) 13:1211-8. doi:10.1038/nm1649

95. Soucek L, Buggy JJ, Kortlever R, Adimoolam S, Monclus HA, Allende MT, et al. Modeling pharmacological inhibition of mast cell degranulation as a therapy for insulinoma. Neoplasia (2011) 13:1093-100. doi:10.1593/neo.11980

96. Nakayama T, Yao L, Tosato G. Mast cell-derived angiopoietin-1 plays a critical role in the growth of plasma cell tumors. J Clin Invest (2004) 114:1317-25. doi:10.1172/JCI22089

97. Xie H, Li C, Dang Q, Chang LS, Li L. Infiltrating mast cells increase prostate cancer chemotherapy and radiotherapy resistances via modulation of p38/ p53/p21 and ATM signals. Oncotarget (2016) 7:1341-53. doi:10.18632/ oncotarget. 6372 
98. Coussens LM, Raymond WW, Bergers G, Laig-Webster M, Behrendtsen O, Werb Z, et al. Inflammatory mast cells up-regulate angiogenesis during squamous epithelial carcinogenesis. Genes Dev (1999) 13:1382-97. doi:10.1101/ gad.13.11.1382

99. Sarchio SN, Scolyer RA, Beaugie C, McDonald D, Marsh-Wakefield F, Halliday GM, et al. Pharmacologically antagonizing the CXCR4-CXCL12 chemokine pathway with AMD3100 inhibits sunlight-induced skin cancer. J Invest Dermatol (2014) 134:1091-100. doi:10.1038/jid.2013.424

100. Tournilhac O, Santos DD, Xu L, Kutok J, Tai YT, Le Gouill S, et al. Mast cells in Waldenstrom's macroglobulinemia support lymphoplasmacytic cell growth through CD154/CD40 signaling. Ann Oncol (2006) 17:1275-82. doi:10.1093/ annonc/mdl109

101. Sinnamon MJ, Carter KJ, Sims LP, Lafleur B, Fingleton B, Matrisian LM. A protective role of mast cells in intestinal tumorigenesis. Carcinogenesis (2008) 29:880-6. doi:10.1093/carcin/bgn040

102. Yang XD, Ai W, Asfaha S, Bhagat G, Friedman RA, Jin G, et al. Histamine deficiency promotes inflammation-associated carcinogenesis through reduced myeloid maturation and accumulation of $\mathrm{CD} 11 \mathrm{~b}+\mathrm{Ly} 6 \mathrm{G}+$ immature myeloid cells. Nat Med (2011) 17:87-95. doi:10.1038/nm.2278

103. Purwar R, Schlapbach C, Xiao S, Kang HS, Elyaman W, Jiang X, et al. Robust tumor immunity to melanoma mediated by interleukin-9-producing $\mathrm{T}$ cells. Nat Med (2012) 18:1248-53. doi:10.1038/nm.2856

104. Siebenhaar F, Metz M, Maurer M. Mast cells protect from skin tumor development and limit tumor growth during cutaneous de novo carcinogenesis in a kit-dependent mouse model. Exp Dermatol (2014) 23:159-64. doi:10.1111/ exd. 12328

105. Hedstrom G, Berglund M, Molin D, Fischer M, Nilsson G, Thunberg U, et al. Mast cell infiltration is a favourable prognostic factor in diffuse large B-cell lymphoma. Br J Haematol (2007) 138:68-71. doi:10.1111/j. 1365-2141.2007.06612.x

106. Dabiri S, Huntsman D, Makretsov N, Cheang M, Gilks B, Bajdik C, et al. The presence of stromal mast cells identifies a subset of invasive breast cancers with a favorable prognosis. Mod Pathol (2004) 17:690-5. doi:10.1038/ modpathol.3800094

107. Amini RM, Aaltonen K, Nevanlinna H, Carvalho R, Salonen L, Heikkila P, et al. Mast cells and eosinophils in invasive breast carcinoma. BMC Cancer (2007) 7:165. doi:10.1186/1471-2407-7-165

108. della Rovere F, Granata A, Familiari D, D’Arrigo G, Mondello B, Basile G. Mast cells in invasive ductal breast cancer: different behavior in high and minimum hormone-receptive cancers. Anticancer Res (2007) 27:2465-71.

109. Rajput AB, Turbin DA, Cheang MC, Voduc DK, Leung S, Gelmon KA, et al. Stromal mast cells in invasive breast cancer are a marker of favourable prognosis: a study of 4,444 cases. Breast Cancer Res Treat (2008) 107:249-57. doi:10.1007/s10549-007-9546-3

110. Tan SY, Fan Y, Luo HS, Shen ZX, Guo Y, Zhao LJ. Prognostic significance of cell infiltrations of immunosurveillance in colorectal cancer. World J Gastroenterol (2005) 11:1210-4. doi:10.3748/wjg.v11.i8.1210

111. Carlini MJ, Dalurzo MC, Lastiri JM, Smith DE, Vasallo BC, Puricelli LI, et al. Mast cell phenotypes and microvessels in non-small cell lung cancer and its prognostic significance. Hum Pathol (2010) 41:697-705. doi:10.1016/j. humpath.2009.04.029

112. Ali G, Boldrini L, Lucchi M, Mussi A, Corsi V, Fontanini G. Tryptase mast cells in malignant pleural mesothelioma as an independent favorable prognostic factor. J Thorac Oncol (2009) 4:348-54. doi:10.1097/JTO.0b013e3181989ddb

113. Welsh TJ, Green RH, Richardson D, Waller DA, O'Byrne KJ, Bradding P. Macrophage and mast-cell invasion of tumor cell islets confers a marked survival advantage in non-small-cell lung cancer. JClin Oncol (2005) 23:8959-67. doi:10.1200/JCO.2005.01.4910

114. Shikotra A, Ohri CM, Green RH, Waller DA, Bradding P. Mast cell phenotype, TNFalpha expression and degranulation status in non-small cell lung cancer. Sci Rep (2016) 6:38352. doi:10.1038/srep38352

115. Chan JK, Magistris A, Loizzi V, Lin F, Rutgers J, Osann K, et al. Mast cell density, angiogenesis, blood clotting, and prognosis in women with advanced ovarian cancer. Gynecol Oncol (2005) 99:20-5. doi:10.1016/j.ygyno.2005.05.042

116. Fleischmann A, Schlomm T, Kollermann J, Sekulic N, Huland H, Mirlacher M, et al. Immunological microenvironment in prostate cancer: high mast cell densities are associated with favorable tumor characteristics and good prognosis. Prostate (2009) 69:976-81. doi:10.1002/pros. 20948
117. Chichlowski M, Westwood GS, Abraham SN, Hale LP. Role of mast cells in inflammatory bowel disease and inflammation-associated colorectal neoplasia in IL-10-deficient mice. PLoS One (2010) 5:e12220. doi:10.1371/ journal.pone.0012220

118. Antsiferova $M$, Martin C, Huber $M$, Feyerabend $T B$, Forster $A$, Hartmann K, et al. Mast cells are dispensable for normal and activin-promoted wound healing and skin carcinogenesis. JImmunol (2013) 191:6147-55. doi:10.4049/jimmunol.1301350

119. Xia Q, Wu XJ, Zhou Q, Jing Z, Hou JH, Pan ZZ, et al. No relationship between the distribution of mast cells and the survival of stage IIIB colon cancer patients. J Transl Med (2011) 9:88. doi:10.1186/1479-5876-9-88

120. Dundar E, Oner U, Peker BC, Metintas M, Isiksoy S, Ak G. The significance and relationshipbetween mastcells and tumour angiogenesisin non-small cell lung carcinoma. J Int Med Res (2008) 36:88-95. doi:10.1177/147323000803600112

121. Tuna B, Yorukoglu K, Unlu M, Mungan MU, Kirkali Z. Association of mast cells with microvessel density in renal cell carcinomas. Eur Urol (2006) 50:530-4. doi:10.1016/j.eururo.2005.12.040

122. Ammendola M, Sacco R, Sammarco G, Donato G, Zuccala V, Romano R, et al. Mast cells positive to tryptase and c-kit receptor expressing cells correlates with angiogenesis in gastric cancer patients surgically treated. Gastroenterol Res Pract (2013) 2013:703163. doi:10.1155/2013/703163

123. Esposito I, Menicagli M, Funel N, Bergmann F, Boggi U, Mosca F, et al. Inflammatory cells contribute to the generation of an angiogenic phenotype in pancreatic ductal adenocarcinoma. J Clin Pathol (2004) 57:630-6. doi:10.1136/jcp.2003.014498

124. Marone G, Granata F, editors. Angiogenesis, Lymphangiogenesis and Clinical Implications, Chem Immunol Allergy. (Vol. 99). Basel: Karger (2014)

125. Folkman J, Shing Y. Angiogenesis. J Biol Chem (1992) 267:10931-4.

126. Grutzkau A, Kruger-Krasagakes S, Baumeister H, Schwarz C, Kogel H, Welker P, et al. Synthesis, storage, and release of vascular endothelial growth factor/vascular permeability factor (VEGF/VPF) by human mast cells implications for the biological significance of VEGF206. Mol Biol Cell (1998) 9:875-84. doi:10.1091/mbc.9.4.875

127. Abdel-Majid RM, Marshall JS. Prostaglandin E2 induces degranulation-independent production of vascular endothelial growth factor by human mast cells. J Immunol (2004) 172:1227-36. doi:10.4049/jimmunol.172.2.1227

128. Theoharides TC, Zhang B, Kempuraj D, Tagen M, Vasiadi M, Angelidou A, et al. IL-33 augments substance P-induced VEGF secretion from human mast cells and is increased in psoriatic skin. Proc Natl Acad Sci U S A (2010) 107:4448-53. doi:10.1073/pnas.1000803107

129. Sismanopoulos N, Delivanis DA, Alysandratos KD, Angelidou A, Vasiadi M, Therianou A, et al. IL-9 induces VEGF secretion from human mast cells and IL-9/IL-9 receptor genes are overexpressed in atopic dermatitis. PLoS One (2012) 7:e33271. doi:10.1371/journal.pone.0033271

130. Boesiger J, Tsai M, Maurer M, Yamaguchi M, Brown LF, Claffey KP, et al. Mast cells can secrete vascular permeability factor/ vascular endothelial cell growth factor and exhibit enhanced release after immunoglobulin E-dependent upregulation of fc epsilon receptor I expression. J Exp Med (1998) 188:1135-45. doi:10.1084/jem.188.6.1135

131. Detoraki A, Granata F, Staibano S, Rossi FW, Marone G, Genovese A. Angiogenesis and lymphangiogenesis in bronchial asthma. Allergy (2010) 65:946-58. doi:10.1111/j.1398-9995.2010.02372.x

132. Varricchi G, Granata F, Loffredo S, Genovese A, Marone G. Angiogenesis and lymphangiogenesis in inflammatory skin disorders. J Am Acad Dermatol (2015) 73:144-53. doi:10.1016/j.jaad.2015.03.041

133. Varey AH, Rennel ES, Qiu Y, Bevan HS, Perrin RM, Raffy S, et al. VEGF $165 \mathrm{~b}$, an antiangiogenic VEGF-A isoform, binds and inhibits bevacizumab treatment in experimental colorectal carcinoma: balance of pro- and antiangiogenic VEGF-A isoforms has implications for therapy. Br J Cancer (2008) 98:1366-79. doi:10.1038/sj.bjc.6604308

134. Bates DO, Mavrou A, Qiu Y, Carter JG, Hamdollah-Zadeh M, Barratt S, et al. Detection of VEGF-A(xxx)b isoforms in human tissues. PLoS One (2013) 8:e68399. doi:10.1371/journal.pone.0068399

135. Harper SJ, Bates DO. VEGF-A splicing: the key to anti-angiogenic therapeutics? Nat Rev Cancer (2008) 8:880-7. doi:10.1038/nrc2505

136. Loffredo S, Borriello F, Iannone R, Ferrara AL, Galdiero MR, Gigantino V, et al. Group V secreted phospholipase A2 induces the release of pro-angiogenic and anti-angiogenic factors by human neutrophils. Front Immunol (2017). (in press). 
137. Baram D, Vaday GG, Salamon P, Drucker I, Hershkoviz R, Mekori YA. Human mast cells release metalloproteinase- 9 on contact with activated T cells: juxtacrine regulation by TNF-alpha. J Immunol (2001) 167:4008-16. doi:10.4049/jimmunol.167.7.4008

138. Rinderknecht M, Detmar M. Tumor lymphangiogenesis and melanoma metastasis. J Cell Physiol (2008) 216:347-54. doi:10.1002/jcp.21494

139. Granata F, Frattini A, Loffredo S, Staiano RI, Petraroli A, Ribatti D, et al. Production of vascular endothelial growth factors from human lung macrophages induced by group IIA and group X secreted phospholipases A2. J Immunol (2010) 184:5232-41. doi:10.4049/jimmunol.0902501

140. Bowers HM Jr, Mahapatro RC, Kennedy JW. Numbers of mast cells in the axillary lymph nodes of breast cancer patients. Cancer (1979) 43:568-73. doi:10.1002/1097-0142(197902)43:2<568::AID-CNCR2820430225>3.0.CO;2-\#

141. Zheng X, Carstens JL, Kim J, Scheible M, Kaye J, Sugimoto H, et al. Epithelial-tomesenchymal transition is dispensable for metastasis but induces chemoresistance in pancreatic cancer. Nature (2015) 527:525-30. doi:10.1038/nature16064

142. Fischer KR, Durrans A, Lee S, Sheng J, Li F, Wong ST, et al. Epithelial-tomesenchymal transition is not required for lung metastasis but contributes to chemoresistance. Nature (2015) 527:472-6. doi:10.1038/nature15748

143. Scheel C, Weinberg RA. Cancer stem cells and epithelial-mesenchymal transition: concepts and molecular links. Semin Cancer Biol (2012) 22:396-403. doi:10.1016/j.semcancer.2012.04.001

144. Pittoni P, Colombo MP. The dark side of mast cell-targeted therapy in prostate cancer. Cancer Res (2012) 72:831-5. doi:10.1158/0008-5472.CAN-11-3110

145. Bry M, Kivela R, Leppanen VM, Alitalo K. Vascular endothelial growth factor-B in physiology and disease. Physiol Rev (2014) 94:779-94. doi:10.1152/ physrev.00028.2013

146. Eruslanov EB, Bhojnagarwala PS, Quatromoni JG, Stephen TL, Ranganathan A, Deshpande C, et al. Tumor-associated neutrophils stimulate $\mathrm{T}$ cell responses in early-stage human lung cancer. J Clin Invest (2014) 124:5466-80. doi:10.1172/JCI77053

147. Zaretsky JM, Garcia-Diaz A, Shin DS, Escuin-Ordinas H, Hugo W, Hu-Lieskovan S, et al. Mutations associated with acquired resistance to PD-1 blockade in melanoma. N Engl J Med (2016) 375:819-29. doi:10.1056/ NEJMoa1604958

148. Varricchi G, Galdiero MR, Marone G, Granata F, Borriello F, Marone G. Controversial role of mast cells in skin cancers. Exp Dermatol (2017) 26:11-7. doi:10.1111/exd.13107

149. Hirschhaeuser F, Sattler UG, Mueller-Klieser W. Lactate: a metabolic key player in cancer. Cancer Res (2011) 71:6921-5. doi:10.1158/0008-5472.CAN-11-1457

150. Gottfried E, Kreutz M, Mackensen A. Tumor metabolism as modulator of immune response and tumor progression. Semin Cancer Biol (2012) 22:335-41. doi:10.1016/j.semcancer.2012.02.009

151. Marone G, Findlay SR, Lichtenstein LM. Adenosine receptor on human basophils: modulation of histamine release. J Immunol (1979) 123:1473-7.

152. Gulliksson M, Carvalho RF, Ulleras E, Nilsson G. Mast cell survival and mediator secretion in response to hypoxia. PLoS One (2010) 5:e12360. doi:10.1371/journal.pone.0012360

153. Walczak-Drzewiecka A, Ratajewski M, Wagner W, Dastych J. HIF-1alpha is up-regulated in activated mast cells by a process that involves calcineurin and NFAT. J Immunol (2008) 181:1665-72. doi:10.4049/jimmunol.181.3.1665

154. Marquardt DL, Gruber HE, Wasserman SI. Adenosine release from stimulated mast cells. Proc Natl Acad Sci U S A (1984) 81:6192-6. doi:10.1073/ pnas.81.19.6192

155. Peachell PT, Columbo M, Kagey-Sobotka A, Lichtenstein LM, Marone G. Adenosine potentiates mediator release from human lung mast cells. Am Rev Respir Dis (1988) 138:1143-51. doi:10.1164/ajrccm/138.5.1143

156. Visciano C, Prevete N, Liotti F, Marone G. Tumor-associated mast cells in thyroid cancer. Int J Endocrinol (2015) 2015:705169. doi:10.1155/2015/705169

157. Lin TJ, Issekutz TB, Marshall JS. SDF-1 induces IL-8 production and transendothelial migration of human cord blood-derived mast cells. Int Arch Allergy Immunol (2001) 124:142-5. doi:10.1159/000053693

158. Jensen-Jarolim E, Achatz G, Turner MC, Karagiannis S, Legrand F, Capron M, et al. AllergoOncology: the role of IgE-mediated allergy in cancer. Allergy (2008) 63:1255-66. doi:10.1111/j.1398-9995.2008.01768.x

159. Chan JK, Roth J, Oppenheim JJ, Tracey KJ, Vogl T, Feldmann M, et al. Alarmins: awaiting a clinical response. J Clin Invest (2012) 122:2711-9. doi:10.1172/JCI62423
160. Subramanian H, Gupta K, Guo Q, Price R, Ali H. Mas-related gene X2 (MrgX2) is a novel G protein-coupled receptor for the antimicrobial peptide LL-37 in human mast cells: resistance to receptor phosphorylation, desensitization, and internalization. J Biol Chem (2011) 286:44739-49. doi:10.1074/ jbc.M111.277152

161. Byrne SN, Beaugie C, O'Sullivan C, Leighton S, Halliday GM. The immune-modulating cytokine and endogenous Alarmin interleukin-33 is upregulated in skin exposed to inflammatory UVB radiation. Am J Pathol (2011) 179:211-22. doi:10.1016/j.ajpath.2011.03.010

162. de Vries VC, Pino-Lagos K, Nowak EC, Bennett KA, Oliva C, Noelle RJ. Mast cells condition dendritic cells to mediate allograft tolerance. Immunity (2011) 35:550-61. doi:10.1016/j.immuni.2011.09.012

163. Rivellese F, Suurmond J, Habets K, Dorjee AL, Ramamoorthi N, Townsend MJ, et al. Ability of interleukin-33- and immune complex-triggered activation of human mast cells to down-regulate monocyte-mediated immune responses. Arthritis Rheumatol (2015) 67:2343-53. doi:10.1002/ art.39192

164. Okayama Y, Hagaman DD, Metcalfe DD. A comparison of mediators released or generated by IFN-gamma-treated human mast cells following aggregation of Fc gamma RI or Fc epsilon RI. J Immunol (2001) 166:4705-12. doi:10.4049/ jimmunol.166.7.4705

165. Daeron M. Innate myeloid cells under the control of adaptive immunity: the example of mast cells and basophils. Curr Opin Immunol (2016) 38:101-8. doi:10.1016/j.coi.2015.12.004

166. Oldford SA, Marshall JS. Mast cells as targets for immunotherapy of solid tumors. Mol Immunol (2015) 63:113-24. doi:10.1016/j.molimm.2014.02.020

167. Shijubo N, Kojima H, Nagata M, Ohchi T, Suzuki A, Abe S, et al. Tumor angiogenesis of non-small cell lung cancer. Microsc Res Tech (2003) 60:186-98. doi:10.1002/jemt.10257

168. Triggiani M, Hubbard WC, Chilton FH. Synthesis of 1-acyl-2-acetyl-snglycero-3-phosphocholine by an enriched preparation of the human lung mast cell. J Immunol (1990) 144:4773-80.

169. Damiani E, Puebla-Osorio N, Gorbea E, Ullrich SE. Platelet-activating factor induces epigenetic modifications in human mast cells. J Invest Dermatol (2015) 135:3034-40. doi:10.1038/jid.2015.336

170. Chacon-Salinas R, Chen L, Chavez-Blanco AD, Limon-Flores AY, Ma Y, Ullrich SE. An essential role for platelet-activating factor in activating mast cell migration following ultraviolet irradiation. J Leukoc Biol (2014) 95:139-48. doi:10.1189/jlb.0811409

171. de Paulis A, Marino I, Ciccarelli A, de Crescenzo G, Concardi M, Verga L, et al. Human synovial mast cells. I. Ultrastructural in situ and in vitro immunologic characterization. Arthritis Rheum (1996) 39:1222-33. doi:10.1002/ art.1780390723

172. Movahedi K, Laoui D, Gysemans C, Baeten M, Stange G, Van den Bossche J, et al. Different tumor microenvironments contain functionally distinct subsets of macrophages derived from Ly6C(high) monocytes. Cancer Res (2010) 70:5728-39. doi:10.1158/0008-5472.CAN-09-4672

173. Motakis E, Guhl S, Ishizu Y, Itoh M, Kawaji H, de Hoon M, et al. Redefinition of the human mast cell transcriptome by deep-CAGE sequencing. Blood (2014) 123:e58-67. doi:10.1182/blood-2013-02-483792

174. Lundstrom SL, Saluja R, Adner M, Haeggstrom JZ, Nilsson G, Wheelock CE. Lipid mediator metabolic profiling demonstrates differences in eicosanoid patterns in two phenotypically distinct mast cell populations. J Lipid Res (2013) 54:116-26. doi:10.1194/jlr.M030171

175. Sotiriou C, Pusztai L. Gene-expression signatures in breast cancer. $N$ Engl $J$ Med (2009) 360:790-800. doi:10.1056/NEJMra0801289

176. Popper HH, Ryska A, Timar J, Olszewski W. Molecular testing in lung cancer in the era of precision medicine. Transl Lung Cancer Res (2014) 3:291-300. doi:10.3978/j.issn.2218-6751.2014.10.01

177. Kim SY, Kim SN, Hahn HJ, Lee YW, Choe YB, Ahn KJ. Metaanalysis of BRAF mutations and clinicopathologic characteristics in primary melanoma. J Am Acad Dermatol (2015) 72:1036-46.e1032. doi:10.1016/j. jaad.2015.02.1113

178. Riquelme I, Saavedra K, Espinoza JA, Weber H, Garcia P, Nervi B, et al. Molecular classification of gastric cancer: towards a pathway-driven targeted therapy. Oncotarget (2015) 6:24750-79. doi:10.18632/oncotarget.4990

179. Coussens LM, Zitvogel L, Palucka AK. Neutralizing tumor-promoting chronic inflammation: a magic bullet? Science (2013) 339:286-91. doi:10.1126/science.1232227 
180. Bedard PL, Hansen AR, Ratain MJ, Siu LL. Tumour heterogeneity in the clinic. Nature (2013) 501:355-64. doi:10.1038/nature12627

181. Mancardi DA, Jonsson F, Iannascoli B, Khun H, Van Rooijen N, Huerre M, et al. Cutting edge: the murine high-affinity IgG receptor FcgammaRIV is sufficient for autoantibody-induced arthritis. J Immunol (2011) 186:1899-903. doi:10.4049/jimmunol.1003642

182. Feyerabend TB, Weiser A, Tietz A, Stassen M, Harris N, Kopf M, et al. Cre-mediated cell ablation contests mast cell contribution in models of antibody- and T cell-mediated autoimmunity. Immunity (2011) 35:832-44. doi:10.1016/j.immuni.2011.09.015

183. De Monte L, Wormann S, Brunetto E, Heltai S, Magliacane G, Reni M, et al. Basophil recruitment into tumor-draining lymph nodes correlates with Th2 inflammation and reduced survival in pancreatic cancer patients. Cancer Res (2016) 76:1792-803. doi:10.1158/0008-5472.CAN-15-1801-T

184. Rodewald HR, Feyerabend TB. Widespread immunological functions of mast cells: fact or fiction? Immunity (2012) 37:13-24. doi:10.1016/j. immuni.2012.07.007

185. Reber LL, Marichal T, Galli SJ. New models for analyzing mast cell functions in vivo. Trends Immunol (2012) 33:613-25. doi:10.1016/j.it.2012.09.008

186. Duluc D, Corvaisier M, Blanchard S, Catala L, Descamps P, Gamelin E, et al. Interferon-gamma reverses the immunosuppressive and protumoral properties and prevents the generation of human tumor-associated macrophages. Int J Cancer (2009) 125:367-73. doi:10.1002/ijc.24401

187. Hagemann T, Lawrence T, McNeish I, Charles KA, Kulbe H, Thompson RG, et al. "Re-educating" tumor-associated macrophages by targeting NF-kappaB. J Exp Med (2008) 205:1261-8. doi:10.1084/jem.20080108
188. Sharma P, Allison JP. Immune checkpoint targeting in cancer therapy: toward combination strategies with curative potential. Cell (2015) 161:205-14. doi:10.1016/j.cell.2015.03.030

189. Tan S, Chen D, Liu K, He M, Song H, Shi Y, et al. Crystal clear: visualizing the intervention mechanism of the PD-1/PD-L1 interaction by two cancer therapeutic monoclonal antibodies. Protein Cell (2016) 7:866-77. doi:10.1007/ s13238-016-0337-7

190. Kleffel S, Posch C, Barthel SR, Mueller H, Schlapbach C, Guenova E, et al. Melanoma cell-intrinsic PD-1 receptor functions promote tumor growth. Cell (2015) 162:1242-56. doi:10.1016/j.cell.2015.08.052

191. Nakae S, Suto H, Iikura M, Kakurai M, Sedgwick JD, Tsai M, et al. Mast cells enhance $\mathrm{T}$ cell activation: importance of mast cell costimulatory molecules and secreted TNF. J Immunol (2006) 176:2238-48. doi:10.4049/ jimmunol.176.4.2238

Conflict of Interest Statement: The authors declare that the research was conducted in the absence of any commercial or financial relationship that could be construed as a potential conflict of interest.

Copyright (®) 2017 Varricchi, Galdiero, Loffredo, Marone, Iannone, Marone and Granata. This is an open-access article distributed under the terms of the Creative Commons Attribution License (CC BY). The use, distribution or reproduction in other forums is permitted, provided the original author(s) or licensor are credited and that the original publication in this journal is cited, in accordance with accepted academic practice. No use, distribution or reproduction is permitted which does not comply with these terms. 